\title{
Proposal for geological classification and nomenclature of soils: both genetic-descriptive and compositional- mineralogical
}

\author{
Luis Enrique Cruz-Guevara ${ }^{1 *}$, Luis Felipe Cruz-Ceballos ${ }^{1}$, Gladys Marcela Avendaño-Sánchez ${ }^{1}$, \\ Mario García-González ${ }^{1}$
}

doi: http://dx.doi.org/10.18273/revbol.v42n1-2020005 (c) (1)

How to cite: Cruz-Guevara, L.E., Cruz-Ceballos, L.F., Avendaño-Sánchez, G.M., and García-González, M. (2020). Proposal for geological classification and nomenclature of soils: both genetic-descriptive and compositional-mineralogical. Boletín de Geología, 42(1), 81-97. doi: 10.18273/revbol.v42n1-2020005.

\begin{abstract}
Numerous systems with detailed classification of soil are in existence. Most of them are based on a variety of complex criteria, such as material type and properties like the amount of organic material, presence of clay layers, and the presence of oxidation or reduction iron-rich horizons, as well as depositional characteristics, its landform morphology and depositional formation processes. Many of these have been developed for use in fields such as agronomy and geotechnics. This paper focuses on the classification of the soil by determining its materials, their origin and the geological processes that shape them, following these basic assumptions: (1) The soil initially comes from the weathering of a parent substrate that can be either sedimentary deposits (for example, alluvial or fluvial) or of any type of rock (igneous, metamorphic or sedimentary), (2) the parent substrate structure is composed by original sequential facies (e.g. foliation, igneous cumulates or stratigraphic intercalation of sedimentary layers), (3) the physical and chemical weathering and the biogenic activity and productivity processes that occur in the soil modify both the original structure and the constituents of the parental substrate, resulting in the formation of new materials, the conservation of others, and the overprint of the sequential facies of the soil (horizons A, B and C) developed on the original parental sequential facies, additionally (4) some materials will be lost from the system and others will be incorporated into it. Finally, a strictly compositional-mineralogical classification of soil is also proposed, which corresponds essentially to the main groups of minerals: silicates, carbonates, phosphates, oxides and hydroxides, sulfates, organic rich matter, nitrates, sulphides, borates, native elements and halides, named in sedimentology as monomaterials, plus the polymaterials or rock fragments (RF). This classification offers an advantage when examining materials that are not genetically linked to the parent substrates, making each soil profile unique, by highlighting the role played by the parental materials in this process. This classification is intended to complement, but not replace any existing soil classification.
\end{abstract}

Keywords: Soil; classification; soil materials; geological classification; genetic classification; compositional classification.

\section{Propuesta de clasificación y nomenclatura geológica de suelos: tanto genética- descriptiva como composicional-mineralógica}

\section{RESUMEN}

Existen numerosos sistemas con clasificación detallada de los suelos, la mayoría de ellos están basados en una variedad de criterios complejos, tales como el tipo de material y propiedades como la cantidad de material orgánico, la presencia de capas de arcilla, y la presencia de horizontes ricos en hierro de oxidación o de reducción, como también de sus características deposicionales, su geomorfología y los procesos de formación de los depósitos. Muchos de estos han sido desarrollados para ser usados en los campos de la agronomía y de la geotecnia. Este escrito se enfoca en la clasificación de los suelos mediante la determinación de sus materiales, su origen y los procesos geológicos que le dan su forma, aceptando las siguientes premisas: (1) el suelo viene inicialmente del intemperismo de un sustrato parental que puede ser o un depósito sedimentario (por ejemplo, aluvial o fluvial) o algún tipo de roca (ígnea, metamórfica o sedimentaria), (2) la estructura del sustrato parental está integrada por facies secuenciales originales (por ejemplo, la foliación, los cúmulos ígneos o la intercalación de capas sedimentarias), (3) el intemperismo físico y químico y los procesos de actividad y productividad biogénica que ocurren en el suelo modifican tanto la estructura original como los componentes del sustrato parental, resultando en la formación de nuevos materiales, la conservación de otros, y la sobreimposición de las facies secuenciales del suelo (horizontes A, B y C) desarrolladas sobre la secuencia de facies originales del sustrato parental, adicionalmente (4) algunos materiales se pierden del sistema y otros pueden ser incorporados dentro de él. Finalmente, se propone una clasificación estrictamente composicional-mineralógica de suelos, la cual corresponde esencialmente a los principales grupos de minerales: silicatos, carbonatos, fosfatos, óxidos e hidróxidos, sulfatos, materia orgánica, nitratos, sulfuros, boratos, elementos nativos y sales, nombrados en sedimentología bajo el término de monomateriales, adicionando los polimateriales o fragmentos de roca (RF). Esta clasificación ofrece una ventaja cuando se examinan los materiales que no son genéticamente relacionados con el sustrato parental, haciendo cada perfil de suelo único, destacando el papel que juega el material parental en este proceso. Con esta clasificación se pretende complementar, pero no reemplazar ninguna clasificación de suelos ya existente.

Palabras clave: Suelo; clasificación; materiales del suelo; clasificación geológica; clasificación genética; clasificación composicional.

${ }^{1}$ Escuela de Geología, Universidad Industrial de Santander, Bucaramanga, Colombia. (*) lecruz@uis.edu.co, luisfelipecruzgeouis@gmail.com,gladysgeology@gmail.com,mgarciag@uis.edu.co 


\section{INTRODUCTION}

The study of the soil is a growing field for multidisciplinary assessment, given its connections with crucial aspects, it is important for the sustainability of life on Earth (Scott and Pain, 2008). Critical zone, in reference to soil, is considered as the delicate skin of the planet (Brantley et al., 2007). It is composed of loose porous materials which store water, atmospheric air and nutrients, creating the best conditions to maintain roots and fauna (FAO, 2015a).

Thanks to a growing research interest, numerous systems of detailed classification of soils have been created, all of them proposed for agrological or geotechnical applications: Casagrande (1948), Birkeland (1999), Soil Survey Staff (1999), Eswaran et al. (2003), Kew and Gilkes (2006), Jahn et al. (2006), The Unified Soil Classification System (USCS) (ASTM D2487-06), Baize and Girard (2008), Geological Survey of Western Australia (2013). Given the complexity of the soils, it is also necessary to analyze them from the geological point of view, studying the relationship that exists between the parent material and the soil that is formed from it.

This document summarizes our efforts to propose a nomenclature for soil descriptions both in field and laboratory, based on their component materials. This paper establishes the baseline for the development of a conceptual framework of genetic-descriptive classification of soils, and a complementary compositional-mineralogical classification. Here we have pointed to a system that is simple but as inclusive as possible. This work uses the existing terms, addresses some clarifications and proposes new ones that aim to complement rather than replace more commonly used nomenclatures. This brief and generalized proposal of soil classification is designed only for interested readers, searchers and students inquiring in characterizing a soil in a different way, which considers the geological characteristics that the researchers in the subject are almost not taken into account, and to be able to quantify the transformations that the parental substratum have suffered to form the soil.

\section{THEORETICAL FRAMEWORK}

Regolith, term introduced by Merrill (1897), is frequently defined by geologists, engineers and agrologists as a layer of loose materials present on the external lithosphere of the Earth, they are a mixed heterogeneous deposit covering solid rock, which include dust, soil, broken rock, organic matter, minerals, gases, liquids, biogenic remains, and other related materials (Merrill, 1897; Scott and Pain, 2008; Chesworth, 2007). Most authors include any sedimentary or recently formed deposits in formation in earth regolith because they are integrated by loose and not consolidated materials, for instance, glacial deposits, colluvium, alluvium, evaporitic sediments, or aeolian deposits present on external lithospheric surface. Additionally, they also state that if earthy regolith contains a significant proportion of biological activity and productivity, they are more conventionally referred to as soil (Chesworth, 2007).

Soil deposits are defined as a coverage-mantle formed in the interface of external lithosphere of the earth and composed of altered and unconsolidated weathering materials, or materials produced as a result of the interaction between the external lithosphere of earth with any atmospheric conditions or fresh or marine water. The soil is the external part of the regolith and does not includes sedimentary deposits, by the contrary the soil is formed from sedimentary deposits, as well as igneous, sedimentary or metamorphic rocks. Moreover, we consider that it is also convenient to separate soil from other sedimentary deposits in formation or recently formed. Soils are a mixture of different materials (organic matter, rock fragments, minerals, elements, ions, gases, liquids, and living organisms, integrated into soil sequential facies (Taylor, 2006) commonly called horizons $\mathrm{O}, \mathrm{A}, \mathrm{B}, \mathrm{C})$. The upper part of soil deposits frequently supports life. Soils are formed depending on the following conditions: climatic (mainly temperature and moisture), biological activity and productivity, topographic (flat or slope), parental material (sequential facies, textures and composition), and incorporated materials, in a place where slowly deposition of new inorganic materials and slowly erosion-deflation processes occurred and the exposition time to weathering condition is long enough to transform some original materials into new ones.

The weathering processes that form soil are characterized by the following processes: compactionreorganization and water loss with release-leaching and denudation of soluble constituents from parental substrate such as calcium, magnesium and silica ions, and clay-layered aluminosilicates materials among others, this was discussed by Kew and Gilkes (2006); dissolution-collapse was described by Al-Amoundi and Abduljauwad (1995); erosion caused by swiftly moving water can scoop out scour holes or irregular erosion 
surfaces named scoured structures, this was discussed by Dvorak and Novak (1994); dehydration-hydration of materials like aluminophillosilicates, gypsum, limonite or other minerals was discussed by Middleton (2003); deposition-incorporation of inorganic materials, for example, formation of layer-clay-aluminosilicates by weathering alteration, was shown by Wilson (1975, 2013); conservation of physical and chemical resistant rocks and minerals (Kew and Gilkes, 2006), named here as inherited and conserved parental materials; deposition-incorporation of inorganic materials was treated by Chesworth (2007) that include e.g. aerosol (cloud and water suspension solid fine materials), sand, and gravel detritus, also of biodetritic materials (reworked organic compounds); deteriorationreorganization-transformation of inorganic materials like nucleic acids, proteins, carbohydrates, lignins, lipids and resins was shown by Pariente and Lavee (2003); incorporation-reorganization of new and preexisting materials by the biological productivity and activity was discussed by Buol et al. (1997), Retallack (1977), Birkeland (1999), and Boggs (2006); transformation of new and preexisting materials by chemical-biological processes (bacterial activity materials) was shown by Chesworth (2007); redistribution of materials (ions and clay) with formation-concentration-coating of isolated clay aggregates or structural clay and fine silt bridging materials between grains and clay layers was treated by Kew and Gilkes (2006); new crystal-precipitationcementation (iron oxides) was described by Ko (2008); formation of some structures (vadose pisolites isolated or forming layers) was shown by Peryt (1983); and finally those fissuring materials on soils induced by ice wedging and/or frost and freezing were treated by Udden (1918), Dylik and Maarleveld (1967) and Benedict (1979).

\section{METHODOLOGY}

To develop our genetic-descriptive classification and compositional-mineralogical classification of soil deposits and rocks, we analyzed and reviewed the methodology and the theoretical foundations of existing soil classifications to identify their strengths and possible contributions based on geological conditions, particularly the substrate on which the soils develops their sequential facies and the mineral compositions of the soil. Among others the classifications consulted are: Unified soil classification system (ASTM D248706), AASHTO soil classification system (ASTM D3282-93(2004)e1), cone penetration test (Robertson and Cabal, 2015), standard penetration test (Soil
Survey Staff, 1999), genetic classification of soil horizons (Soil Survey Staff, 2014), international world reference base (WRB) soil classification system (IUSS Working Group WRB, 2015), Canadian system of soil classification (Soil Classification Working Group, 1998), classification of organic soils (Huang et al., 2009), revised classification system for regolith (Geological Survey of Western Australia, 2013). In addition to the classifications consulted, Millot (1964) proposal for clay materials in soils was analyzed. Then, we genetically defined the groups of materials that make up the soils into three types: inherited, incorporated and transformed materials. We listed the processes that vary the proportions of these materials in the soil profile, and generated a nomenclature using the variation of these materials in the composition of soil. Additionally, we applied this proposition to study five modern soil places with different kinds of parental substratum: quartz sandstone from Los Santos Formation of Lower Cretaceous, Limestones from Rosablanca Formation of Lower Cretaceous, Sienogranite from Pescadero Granite, Feldesphaticbiotite-quartz Gneiss from Bucaramanga Neis, and Recent unconsolidated fluvio torrential deposits, see Avendaño-Sánchez and Cruz-Ceballos (2017). Soil developed on quartz sandstone lithology form Los Santos Formation used here as example is located on "El Duende" cascade - "La Purnia" secondary road (La Mesa de Los Santos-Santander-Colombia, South America), coordinates with datum Bogotá X: 1'111590,048m, Y:1'252370,546m, and 1656 m.a.s.l. This sampling place corresponds geomorphologically to the upper part of a structural plateau (Mesa de Los Santos) with sub horizontal to horizontal strata (dips smaller than $5^{\circ}$ ), the geomorphological slope is smooth (inclination from 0 to $4^{\circ}$ ) according to the slope map generated from a Digital Elevation Model (DEM), the climate classification of the site is temperate semihumid (Tsh) based on climate classification CaldasLang 2012 (IDEAM, 2017), more detailed information in Avendaño-Sánchez and Cruz-Ceballos (2017).

\section{RESULTS}

\section{General classification of soil deposits}

The geological parameters that must be taken into account when studying and classifying soils are as follows: (1) The structure and the materials that integrate de soil: the structural parameters include the inherited sequence facies (Isf) from parental substratum and the soil sequence facies (Ssf) (Figure 1). The Isf, integrated by either: sedimentary stratigraphic bed 
sequences, metamorphic foliation, schistosity and gneissosity, or igneous homogeneous or heterogeneous cumulates. The Ssf that correspond to A, B, C horizon, the later Ssf are overprinted on the original parental substratum sequential facies (Pssf). The following 2 to 6 parameters which should be specifically considered in each of the sequence facies (Pssf, Isf, Ssf) separately, (2) the three dimensional (3D) geometric shape of the parental substratum (mantle, tabular, lenticular, etc.), (3) the internal structural characteristics (homogeneity $v s$ heterogeneity) in terms of lamination, graded bed, or sedimentary deformation structures, or igneous or metamorphic cumulus etc., (4) the genetic materials that make up the soil deposit includes the inheritedconserved materials from parental substratum, the incorporated materials into the soil deposit and finally the transformed materials from both inherited and incorporated materials (Cruz-Guevara et al., 2017), for more specific details see Table 1, (5) the textural categories (framework, matrix, cement, pores, and clast, seudoclast and crystal size), (6) the compositionalmineralogical characteristic (Rock fragment (RF), siliceous, calcareous, organic rich, etc.).

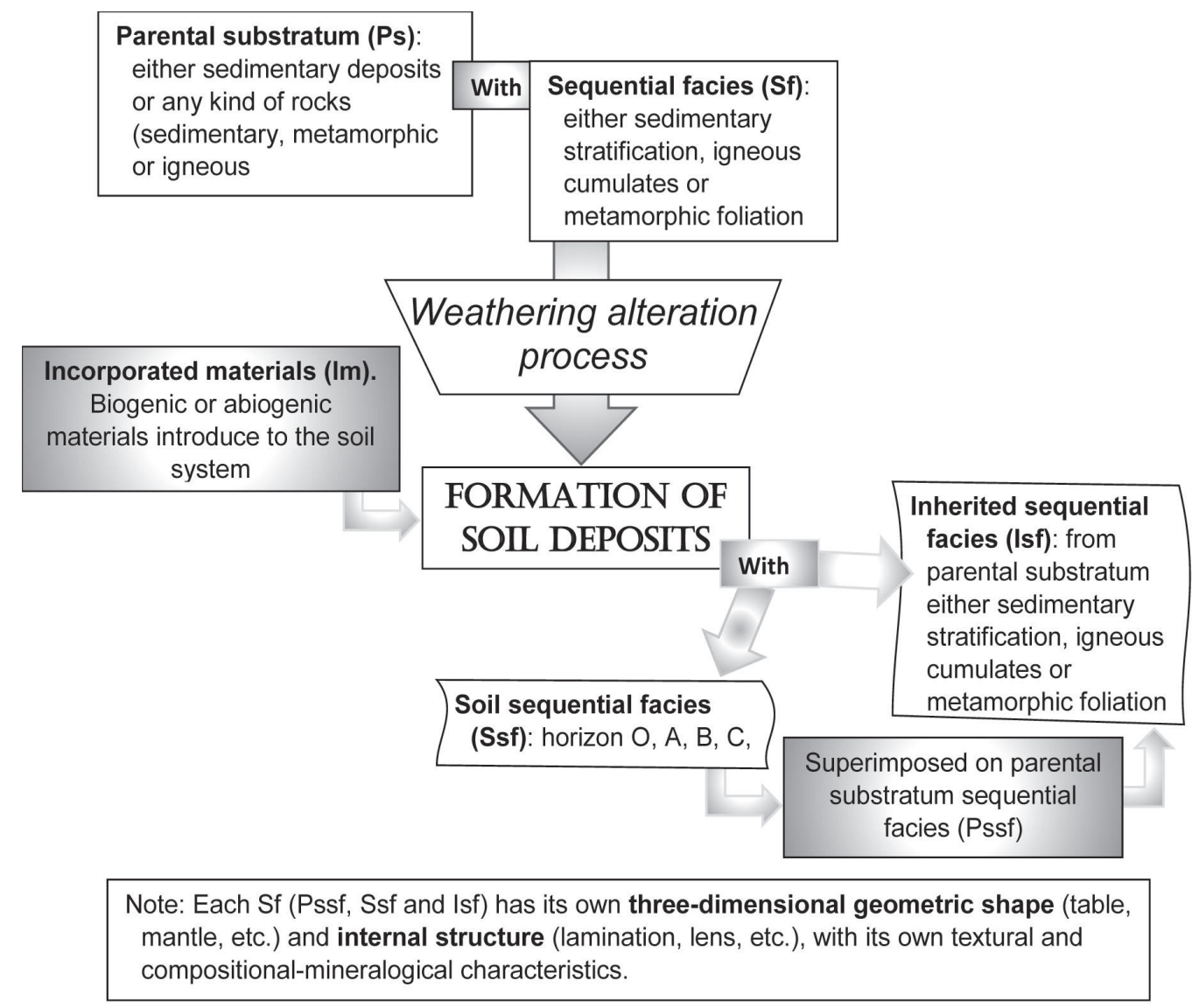

Figure 1. Flow chart showing the sequence of events and entities in the formation of soil, since the parental substratum is exposed to weathering process, and the different sequential facies (Sf) involved in the process.

The study of soils implies the consideration also of (7) the diagenetic factor, which involves early diagenesis (weathering and soil formation, bioperturbation, soft sedimentary deformation (SSD), early cementation and early dissolution, etc.), late diagenesis (cementation, dissolution-cavity formation, dissolutionneomorphism, dissolution-collapse, etc.), and finally also includes aspects of retrodiagenesis (Do Campo et al., 2017), (8) the tectonic factor (tectonically ductile deformations such as folds, fragile disruptions, lineations of penetrative cracks, shear zones and faults present in the soil profile), (9) Epigenesis factor, any material that has been formed by crystalline precipitation after lithification at low temperature and pressure, and located along structural elements such as faults and fractures, it includes crystalline 
precipitation structures and materials, veins of quartz, calcite, gypsum, etc., and excludes hydrothermal and related veins, and finally (10) the inferential time factor (succession of events).

Sequential facies is a term proposed by Taylor (2006) for the sequential intercalation of facies that characterize a soil, for the purpose of this paper, this term will be used also for the rest of sedimentary deposits, and for igneous, metamorphic or sedimentary rocks.

Sequence facies $(\mathrm{Sf})$ are fundamental in soil formation, they involve some 3D shape and some lineation of mineral in any size with rhythmic intercalation. In metamorphic rocks $\mathrm{Sf}$ are foliation, schistosity, gneissosity, and relatives, in sedimentary deposits or rocks Sf are intercalation of beds of any composition and texture, and in igneous rocks Sf are commonly homogeneous and isotropic structures, or moderately layered plutonic structures named igneous cumulates. Igneous cumulates were described by Wager et al. (1960), for alignment of crystals with intercalation of mantles of different lavic events by differential crystallization of minerals.

The Ssf and Isf contribute significantly to the behavior of soils, for agricultural purposes and also in engineering, specifically in terms of geotechnical uses, for stability and threat, vulnerability and risk of natural slope (Patton, 1966; Patton and Deere, 1971). For example, a parental rock composed of an intercalation of very thick layers of quartz sandstone cemented by quartz, with any structural condition, offers the worst scenario for soil development regardless of weather conditions, because it does not have enough space to store water, oxygenated atmospheric air and nutrients, additionally, there is limited probability that weathering can degrade their materials. In conclusion, a soil with the above mentioned characteristics presents the worst conditions for agricultural purposes, but the best geotechnical conditions for foundation of engineering structures like buildings, bridges, etc.

If the parental rock is composed by an intercalation of clay argillosilicates, these materials develop fissility, cracks and fractures by decompression or by weathering; these conditions allow the penetration of the roots and the easy development of soil. Soils with these characteristics are good as substrate for agricultural purposes and lack the conditions necessary for the foundation of engineering structures.
The soil has different and particular facies with a sequential relationship ( $\mathrm{O}, \mathrm{A}, \mathrm{B}, \mathrm{C}$, horizons), the geometry of the different parts of the soil, the horizons, have an irregular layered mantle shape, integrated with different kinds of materials, and positioning one part on another, with uniform or variable thickness and variable lateral extension as well. In general, there are three or four horizons integrating the soil (Bridges, 1990; Jahn et al., 2006), here referred as the term "Typical sedimentary soil sequence (Tsss)": 1) the uppermost part named $\mathrm{O}$ horizon, frequently correspond to the organic soil, which is mainly composed by biogenic and abiogenic incorporate materials, which are frequently transformed or degraded due to the weathering conditions; 2) the underlying of O level integrated by altered parental substratum, frequently subdivided into $\mathrm{A}, \mathrm{B}$ and $\mathrm{C}$ horizons, characterized by each presenting a different intensity of transformation by weathering, a different amount of both incorporated and loss materials, and 3 ) the underlying are unaltered parental substratum (any sedimentary deposit or any type of rock). The Pssf exposed to weathering process during a prolonged space of time, and slow erosiondeflation of materials, results on the develop of an overprint of the soil horizon A, B and C over the initial Pssf (one example of this situation is presented in Figure 2).

The first approximation to the geologic and genetic classification of soil refers to the determination of their parental substratum, a parental rock soils (Prs) or a parental deposit soil (Pds), in consequence Prs overlies bedrock and Pds overlies unconsolidated sedimentary deposits. Specific examples that use this genetic classification proposal are: Parental gneiss soil, parental quartz sandstone soil, parental limestone soil, etc. It is necessary that the description of the parental substrate and their Pssf be as specific and complete.

As a complement to the genetic classification presented above, the second genetic approach to soil classification is based on the three types of genetic materials that form the soils (Cruz-Guevara et al., 2017), this proposition follows in part the scheme proposed by Millot (1964) "clay minerals in a sedimentary basin can be neoformed, inherited or transformed". In this work we also used the Birkeland (1999) scheme presented in Boggs (2006), the processes that modify the characteristics of the soil are: 1) addition to the ground, 2) transformation, 3) transfers, 4) removals, and 5) bioturbation of soil. Agreeing with this, soil materials and structures can 
be integrated into three types of genetic materials, see Table 1: 1) inherited and conserved materials ( $\mathrm{Icm}$ ), those biogenic and inorganic materials released by the degradation of the parent substrate caused by weathering. They are resistant materials such as rock fragments, amber, kerogen materials, and mono materials like quartz, zircon, ilmenite, among others. 2) incorporated materials ( $\mathrm{Im}$ ), those biogenic or abiogenic materials incorporated into the soil by any of the following processes: clastic deposition, chemical precipitation accumulation, biogenic productivity or activity, also the material incorporated during diagenesis; and 3) transformed, deteriorate or redistributed materials (Tdrm), those materials formed inside the soil by transformation, deterioration or redistribution process of original materials whatever inherited or incorporated. The specific materials of the soil of each of the three groups, materials inherited, conserved, incorporated and transformed, deteriorated or redistributed are presented in the Table 1.

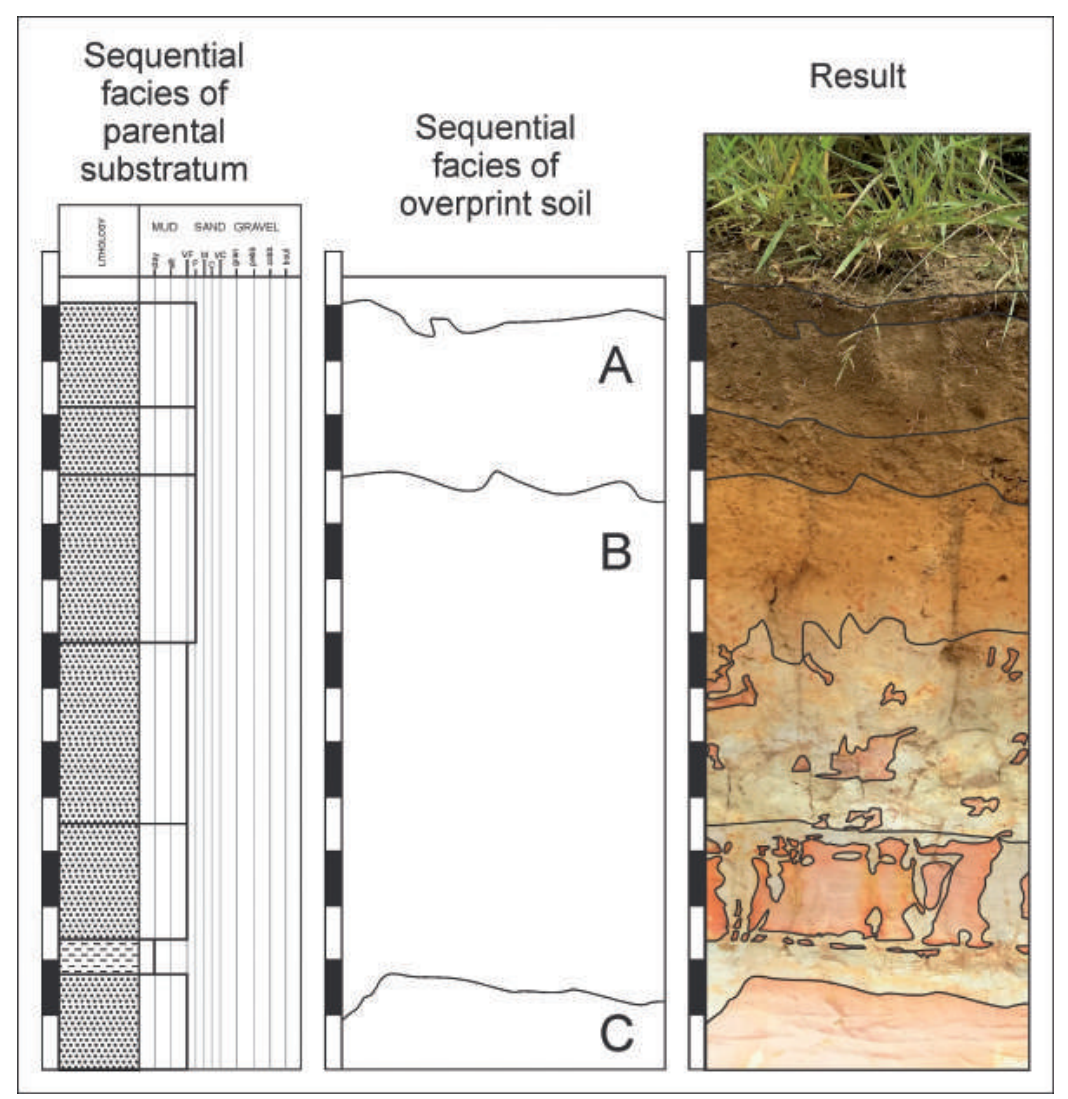

Figure 2. Soil profile developed over parental sequential facies, an alternation of fine to very fine feldspathic quartz sandstones with a small level of argillosilicate bed from Los Santos Formation. The Isf are presented in left stratigraphic column, with the distribution of grain size of the materials. The overprint sequential facies of the developed soil (horizons A, B and C) are presented in the central image. After Avendaño-Sánchez and Cruz-Ceballos (2017).

One of the most important parameters used in the classification of the soil is the intensity of the transformations they have had, this depends on: deposition rates of the sediments, the deflation intensity of the materials, the temporary exposure to the weathering conditions and the specific climatic conditions (humidity and temperature mainly). The genetic classification of the soil using TDRM, ICM and IM, and a ternary diagram is shown in Figure 3 , the exposure time conditions, brief or prolonged to the weather conditions, the type of climate (arid and/or cold, humid and warm), and erosion intensity denudation (green arrow), are expressed to show their relationship with the inherited, incorporated and transformed materials and the intensity of the transformations of these materials. 
Table 1. Soil materials and structures (Rms) according to their genetic condition.

Fundamental materials and structures

\section{Specific materials and description}

Rock fragments pseudoparticles of igneous plutonic, hypabyssal, volcanic, among others, metamorphic quartzite, marble, hornfels, schist, phyllite, slate, gneiss, cataclastic, among others, Inherited and conserved or sedimentary soil, clastic, biogenic, chemical or diagenetic.

Inherited and conserved
pseudoparticles (Icpp): Solid Light and heavy "Crystals" pseudoparticles of quartz, zircon, ilmenite, etc., inherited-conserved preserved materials release by from igneous or metamorphic rocks.

Inherit ed - conserved weathering partial alteration-

materials (Icm), those destruction of parent substratum: Biogenic pseudoparticles: biogenic production inherited and conserved from sedimentary rocks rocks or isolated biogenic or Resistant materials named (corporal bioliths, bioconstruction, etc.)

inorganic materials inherited pseudoparticles of silt, sand and Chemical sedimentary pseudoparticles: pure abiogenic chemical formation-accumulation and conserved from parent substratum.

pseudoparticles of silt, sand and
gravel that look like particles but without any transportation.

materials inherited and conserved from sedimentary rocks (gypsum crystals, abiogenic ooids, etc.)

Diagenetic pseudoparticles: original diagenetic modification-transformation materials inherited and conserved from sedimentary rocks (e.g., hematitic ooids, calcareous concretions, etc.).

Inherited and conserved particles (Icp): gravel, sand and mud particles inherited and conserved from clastic sedimentary parental rocks or sedimentary deposits.

Particles (Ip): isolated deposition of gravel, sand and mud particles transported by gravity, water or wind; mud materials include clay bond aggregates formed in aerosol, water, cloud and snow, e.g. tropolites and relatives.

Juvenile biogenic autochthonous materials (Ijbam): juvenile biogenic production formed directly or accumulated (corporal Incorporated materials biomineralized materials: shells, bones, pollen, spores among others; corporal tissues and organs; biodepositional materials (Im), those biogenic (biogenic excretion or exudation); and, materials formed by organism's activities: bioconstructions, and biofoodcaches materials or abiogenic materials and structures; bioerosion structures; biotools, biominerals, and biodetritus materials; coated microbial-chemical materials or incorporated into the soil by structures.

any clastic sedimentation, chemical precipitation accumulation, biogenic productivity and activity, or by diagenetic process that
include authigenic materials.

Natural liquids and gases materials (Inlgm): that include "atmospheric water and gas" in their natural state.

"Leaked and infilling materials" (Ilm) or younger materials piped down mechanically into the deposits through cavities (burrows or fissures) (Kidwell et al., 1986), and infilling particulate materials (mud-sand-gravel) fine or coarse grained inside of the empty natural space (poral or biological cavities).

Authigenic materials (Iam): any kind of new mineral precipitation that is form or grown inside the soil deposits, include cement and relatives like silicates (quartz, feldspar, layer aluminosilicates, amorphous silica, among others), carbonates, phosphates, iron, manganese, aluminium and titanium oxide and hydroxide, sulfates and salts, nitrates and ammonium, sulphides, borates, and native elements.

Weathering alteration materials (Wam): those materials formed by weathering transformed-deteriorated process of labile materials (e.g. feldspar, pyroxenes etc.), include layer-clay aluminosilicates minerals (e.g. kaolinite, among others), materials that look like clay particles but are not, they are pseudoparticles.

Desiccation-contraction materials and structures (Jdcms), that include desiccation peloids, mud shrinkage cracks, and crack systems with polygonal pattern by the growth of dolomite and/or evaporite minerals (e.g. Assereto and Kendall, 1971; Bellamy, 1977).

Scoured materials and structures (JSms) caused by swiftly moving water, can scoop out scour holes or irregular erosion surface

Ice wedging and/or frost and freezing fissuring materials and structures (Jiwfffms), those induced by soil freezing, (e.g. Udden, 1918; Dylik and Maarleveld, 1967; Benedict, 1979).

Redistributed inorganic materials and structures (Rdims): materials formed by redistribution of layer-clay aluminosilicates minerals (e.g. kaolinite), and coated or flocculated clay aggregates, isolated or structural clay, and fine silt bridging material between grains and clay layers (Kew and Gilkes, 2006).

Transformed-deteriorated Bio-redistributed materials and structures (Brdms): inorganic materials and biological remains mixing, redistributed and deteriorate and redistributed materials (Tdrm), those materials that formed inside the soil by TDR process of original inherited materials.

by biological activity that include remobilization and reorientation of material.

Soft deformation and remobilization materials and structures (Jsdrms): deformation, injection and remobilization structures formed in sedimentary deposits by seismic activity (Bohra et al., 2014), or gravity, or fluidification-liquefaction: load casts, tee-shear (ice-push), flame, load, diapiric sand-mud structures, pseudonodule (Macar, 1948), ball-and-pillow structure (Smith, 1916) and relatives.

Dissolution and dissolution-collapse materials and structures (Jddcms): obliteration of unstable materials and consequently formation of dissolution structures like, poral and cavities, stylolites and/or collapse pseudobreccias (collapse breccias of Friedman, 1997).

Ion remobilization and segregation materials and structures (Jirsms): intraestratal dissolution of unstable materials, with remobilization, segregation and precipitation of materials to form nodules, concretions and relatives

Neomorphism materials and structures (Mms): any kind of mineral that is transformed by chemical recrystallization or mineral inversion or replacement of original materials.

Mixed biological and weathering materials and structures (Mxjbwms): any material formed by a mixed biological-weathering process, e.g, microbial-desiccation-weathering materials and structures.

Degraded biogenic-organic compounds materials and structures (Dbocms): materials formed by chemical-biogenic deteriorationreorganization-transformation of organic materials like nucleic acids, proteins, carbohydrates, lignin, lipids and resins, into gases, liquids and solids hydrocarbons and relatives. 


\section{Transformed - deteriorated}

\section{and redistributed materials}

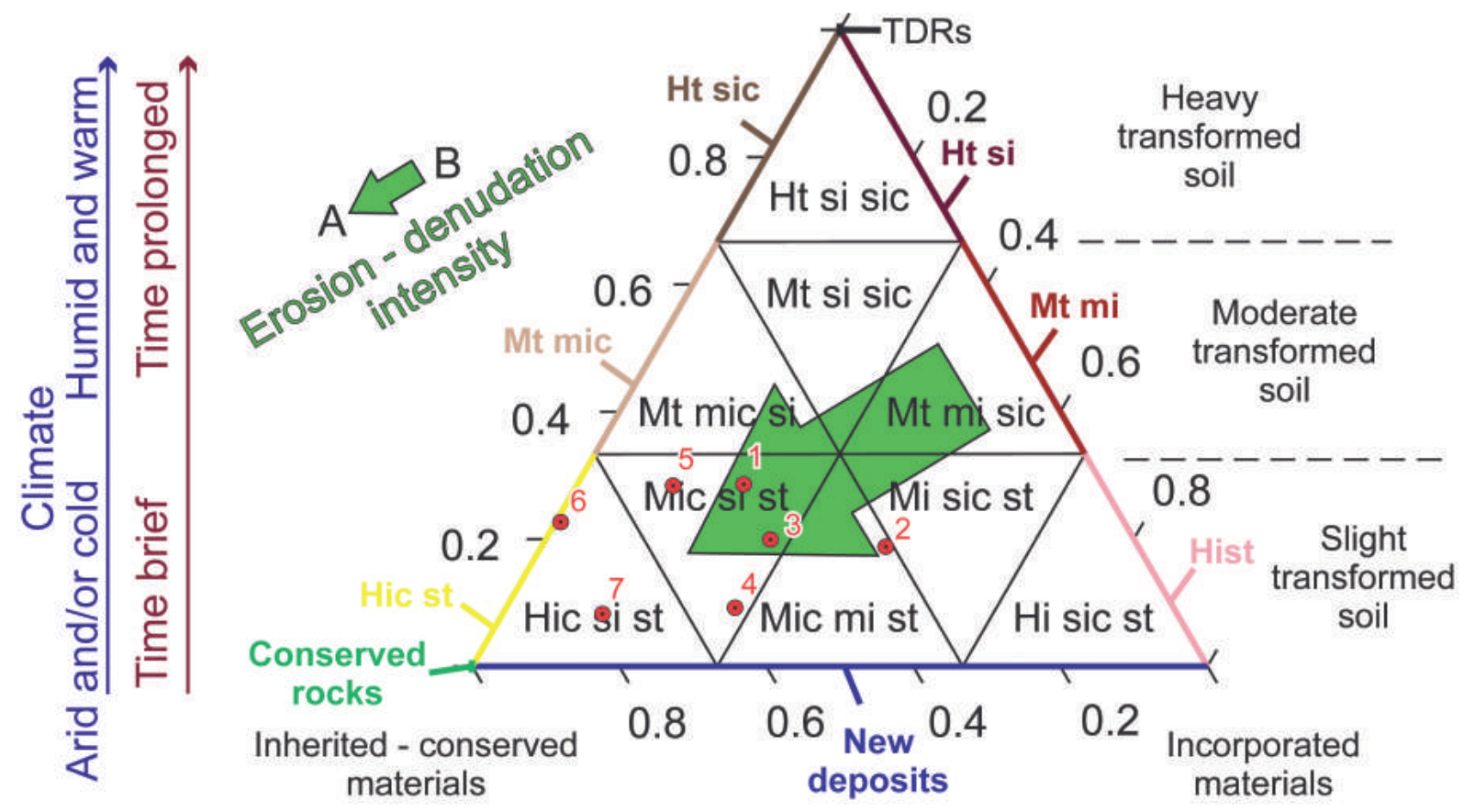

Figure 3. General classification of soils deposits (Avendaño-Sánchez and Cruz-Ceballos, 2017) based on inherited and conserved parental materials (Icm), incorporated materials (Im), and transformed-deteriorated-redistributed materials (Tdrm). Plotted Ipsf, numbers 1 to 7 on red color of the feldsphatic quartz arenite succession sample from Los Santos Formation. Transformation intensity: Heavy $(\mathrm{H})$, moderately $(\mathrm{M})$ and slightly $(\mathrm{S})$. Green arrow shows erosion-denudation intensity, where A is strong denudation and $\mathrm{B}$ is slight denudation of soil.

According to the transformations suffered by the materials that make up the soil, presented in the TDRM-ICM-IC diagram (Figure 3), these systematic that partly resembles the classification for the rocks of weathering of Lavaut (2018) and saprock term (rocks with light weathering) of Trescases (1975), these four soil types are proposed: 1) Totally transformeddeteriorated and redistributed soil deposits (Tts), in which the original materials inherited or incorporated were totally transformed-deteriorated and/or redistributed; 2) heavily transformed-deteriorated and redistributed soil deposits (Hts), in which more than $66,6 \%$ original materials inherited or incorporated were transformed-deteriorated and/or redistributed; 3 ) moderately transformed-deteriorated and redistributed soil deposits (Mts), in which between 33,3 to $66,6 \%$ original materials inherited or incorporated were transformed-deteriorated and redistributed; and, 4) slightly transformed soil deposits (Sts), in which less than $33,3 \%$ original materials inherited or incorporated that were transformed-deteriorated and redistributed, in this type of deposits, the main materials are the materials incorporated and/or the materials inherited and conserved, in quantities from moderately to heavily. Table 2 shows the denominations for specific types of soils that appear in the ternary diagram of Figure 3.

\section{Compositional-mineralogical classification and naming of soil deposits}

The mineral composition contributes significantly to the behavior of soils, minerals and organic matter present in soils, maintains and stores nutrients, and is an important aspect of nutrient management. For example, parental substrate of the soil is integrated mainly by silicate minerals, they are $90 \%$ of the minerals present in the earth's crust, and the silicateweathering reactions do not follow the rhythm of the highest acid deposition load. Acid deposition of soil has been implicated as a factor contributing to forest decline, increase leaching of plant nutrients, decrease levels of nutrient cation, increase concentration of potentially toxic metals, alter the solubility of organic compounds, and impose changes in population of soil 
organisms (Chesworth, 2007). There are different mineral components in the soils, many of them are very common in the other types of sedimentary deposits and rocks, the definition of the mineral classes that we took into account for the classification are based on the main mineralogical groups proposed by Dana and Ford (1922) and Dana and Hurlbut (1959). In addition, silicates, carbonates, phosphates, etc., are present in soils and other deposits and sedimentary rocks in the form of mono-materials, but are also present as rock fragments (RF), which are considered also as polymaterials. The compositional classification of soils is presented in Table 3.

Table 2. Terms applied for specific genetic classification of soil deposits, according to the transformation-deterioration and redistribution of the original materials. Delimited in the triangular diagram Figure 3.

\begin{tabular}{|c|c|c|}
\hline \multicolumn{2}{|c|}{ Generic genetic classification } & Specific genetic classification \\
\hline \multicolumn{2}{|c|}{ Totally transformed soil (Tts) } & $\begin{array}{l}\text { Where original inherited and/or incorporated materials was totally transformed-deteriorated and/or } \\
\text { redistributed. }\end{array}$ \\
\hline \multirow{3}{*}{\multicolumn{2}{|c|}{ Heavily transformed soil (Hts) }} & $\begin{array}{l}\text { Ht si. Heavily transformed soil deposits with slightly original incorporated materials that are still } \\
\text { conserved. }\end{array}$ \\
\hline & & $\begin{array}{l}\text { Ht sic si. Heavily transformed soil deposits with slightly original inherited and/or incorporated } \\
\text { materials that are still conserved. }\end{array}$ \\
\hline & & $\begin{array}{l}\text { Ht sic. Heavily transformed soil deposits with slightly inherited-conserved parent rocks materials } \\
\text { that are still conserved. }\end{array}$ \\
\hline \multirow{5}{*}{\multicolumn{2}{|c|}{ Moderately transformed soil (Mts) }} & $\begin{array}{l}\text { Mt mi. Moderately transformed soil deposits with moderately incorporated materials that are still } \\
\text { conserved. }\end{array}$ \\
\hline & & $\begin{array}{l}\text { Mt mi sic. Moderately transformed soil deposits with moderately incorporated that are still } \\
\text { conserved and slightly inherited-conserved parent rock materials. }\end{array}$ \\
\hline & & $\begin{array}{l}\text { Mt sic si. Moderately transformed soil deposits with slightly inherited-conserved parent rock and } \\
\text { slightly incorporated materials that are still conserved. }\end{array}$ \\
\hline & & $\begin{array}{l}\text { Mt mic si. Moderately transformed soil deposits with moderately inherited-conserved parent rock } \\
\text { and slightly incorporated materials that are still conserved. }\end{array}$ \\
\hline & & $\begin{array}{l}\text { Mt mic. Moderately transformed soil deposits with moderately inherited-conserved parent rock } \\
\text { materials. }\end{array}$ \\
\hline \multirow{7}{*}{$\begin{array}{l}\text { Slightly } \\
\text { transformed soil } \\
\text { (Sts) }\end{array}$} & \multirow{4}{*}{$\begin{array}{l}\text { Heavily and } \\
\text { moderately } \\
\text { incorporated }\end{array}$} & Hi st. Heavily incorporated soil deposits slightly transformed. \\
\hline & & $\begin{array}{l}\text { Hi sic st. Heavily incorporated soil deposits with slightly inherited-conserved parent rock materials, } \\
\text { slightly transformed. }\end{array}$ \\
\hline & & $\begin{array}{l}\text { Mi sic st. Moderately incorporated soil deposits with slightly inherited-conserved parent rock } \\
\text { materials, slightly transformed. }\end{array}$ \\
\hline & & $\begin{array}{l}\text { Mic-mi st. Moderately incorporated-moderately inherited-conserved soil deposits, slightly } \\
\text { transformed. }\end{array}$ \\
\hline & \multirow{3}{*}{$\begin{array}{l}\text { Heavily and } \\
\text { moderately } \\
\text { inherited- } \\
\text { conserved }\end{array}$} & $\begin{array}{l}\text { Mic si st. Moderately inherited-conserved soil deposits, with slightly incorporated materials that are } \\
\text { still conserved, slightly transformed. }\end{array}$ \\
\hline & & $\begin{array}{l}\text { Hic si st. Heavily inherited-conserved with slightly incorporated materials that are still conserved } \\
\text { soil deposits, slightly transformed. }\end{array}$ \\
\hline & & Hic st. Heavily inherited-conserved materials soil deposits, slightly transformed. \\
\hline
\end{tabular}

Lithic rich soils: The soil rich in rock fragments (RF) or lithic, RF is a term of sedimentology which refers to any sedimentary material that retains the original characteristics of its parent rocks. The fragments of rock form in the soil both particles and also materials preserved after weathering that do not have any type of transport (pseudo-particles). Many soils are rich in RF (Bornemann et al., 2011).

Silicate rich soils: The silicates are any member of a family of minerals that contain silicon and oxygen anions, such as quartz, amorphous silica (chalcedony, glass), feldspar, zircon, mica group minerals (biotite, muscovite, etc.). Soils rich in silicate include siliceous rich soil (Silcrete), argillaceous soil formed by argillaceous weathering materials (kaolinite, montmorillonite-smectite, illite, sericite). The silicates form in the soil the following sedimentary materials: particles, pseudo particles, and authigenic materials. Particularly amorphous silica (opaline) form in the soil the following sedimentary materials: particles, biogenic, bioclastic, sedimentary crystals, weathering microcrystalline alteration, and authigenic materials. 
Table 3. General compositional-mineralogical classification of soils deposits.

\section{Main compositional-mineralogical groups of soils deposits}

1. Lithic rich soils (S): Soil rich in rock fragment.

2. Silicate rich soils: Silcrete, argillaceous clay rich S.

3. Carbonate rich soils: Calcrete $\mathrm{S}$.

4. Phosphate rich soils.

5. Iron, manganese, aluminium and titanium oxide and hydroxide rich soils: lateritic, oxysoils.

6. Sulfate and salts rich soils.

7. Organic rich soils: Histosol (FAO, 2015b).

8. Nitrates rich soils.

9. Sulphides rich soils.

10. Borates rich soils.

11. Native elements rich soils.

12. Mixed compositional rich soils: silicate-carbonate, silicate-phosphorite, oil shale, oil sands, etc.

Notes: Soil has natural air and gases filling their porous space, include atmospheric air, methane and relatives, and other natural gases. Soil also has natural water and liquid filling their porous space, include meteoric water, organic liquid and relatives, and other natural liquid.

The last 8 to 11 groups of deposits or rocks are less abundant but economically important.

Carbonate rich soils: The carbonates are minerals that contain carbonate ion $\left(\mathrm{CO}_{3}^{2-}\right)$ combined with divalent cations. Soils rich in carbonates include socalled calcrete soils, which contain calcite, aragonite, dolomite, magnesite, siderite. The carbonates form in the soil the following sedimentary materials: particles, biogenic, bioclastic, pseudo particles, sedimentary crystals, weathering alteration and precipitation microcrystalline and authigenic materials.

Phosphate rich soils: The phosphates are minerals that contains phosphate ion $\left(\mathrm{PO}_{3}^{4-}\right)$. Soils rich in phosphate have apatite, fluorapatite, wavellite. They form in soil the following sedimentary materials: particles, biogenic, bioclastic, pseudo particles, and authigenic materials (francolite, collophanite). Soil weathering causes dissolved phosphate from primary minerals (especially as apatite, calcium phosphate, Tiessen et al., 1984) to precipitate with some cations and lead, for example, to the neo-formation of calcium phosphate in alkaline soils (Beck and Sanchez, 1994), adsorbed by functional groups of iron or aluminium oxides to form thermodynamically stable complexes (Bortoluzzi et al., 2015; Fink et al., 2016) or form biologically active organic compounds that remain as organic phosphate in soil (Conte et al., 2002; Martinazzo et al., 2007; Dodd and Sharpley, 2015).

Iron, manganese, aluminium and titanium oxide and hydroxide rich soils: They are soils with iron oxide and hydroxide materials (goethite, limonite, ferrihydrite), manganese oxides (lithiophorite, hollandite, and birnessite), aluminium hydroxide (gibbsite), and titanium oxides and hydroxides (less common). All of them form in the soil the following sedimentary materials: sedimentary crystals, weathering alteration microcrystalline materials, pseudo particles, and authigenic materials. Goethite and hematite are the most common pedogenic iron oxides, accompanied by maghemite and ferrihydrite in small amounts (Kämpf and Schwertmann, 1982; Schaefer et al., 2008; Carvalho-Filho et al., 2015). Pedogenic aluminium oxides contain mainly gibbsite found near the equatorial line. Ferrihydrite and lepidocrocite are found in poorly drained soils (Wang et al., 2013). A laterite is a soil layer that is rich in iron oxide (goethite, $\mathrm{HFeO}_{2}$; lepidocrocite, $\mathrm{FeO}(\mathrm{OH})$; and hematite, $\mathrm{Fe}_{2} \mathrm{O}_{3}$ ), also contains titanium oxides and hydrated oxides of aluminum (gibbsite, $\mathrm{Al}_{2} \mathrm{O}_{3} \cdot 3 \mathrm{H}_{2} \mathrm{O}$, and bauxite). Lateritic soils may contain clay minerals, but they tend to be silica-poor. Laterites are derived from a wide variety of rocks weathering under strongly oxidizing and leaching conditions, in tropical and subtropical regions where the climate is humid.

Sulfate and salts rich soils: The sulfates are minerals that contain the anion $\mathrm{SO}_{4}^{2-}$. A salt is a chemical compound formed by cations (positively charged ions) linked to anions (negatively charged ions) by an ionic bond. Include soils with sulfates (gypsum) and salts (halite). They form in soil the following sedimentary materials: particles, weathering alteration microcrystalline materials, pseudo particles, and authigenic microcrystalline to mega-crystalline materials.

Organic rich soils: The organic compounds refer to materials with the large pool of carbon-based compounds (CHON), the basic structure of them are created directly by secretion of organisms: cellulose, 
tannin, cutin, and lignin, along with other various proteins, lipids, and carbohydrates. Soil with organic compounds include histosoil (FAO, 2015b), organic compounds form in the soils the following materials: coal, kerogen, wax, paraffin, petroleum, methane, etc. They form in soil the following sedimentary materials: particles, biogenic, bioclastic, pseudo particles, weathering alteration and diagenetic materials.

Nitrates rich soils: The nitrates are minerals with the ion with chemical formula $\mathrm{NO}^{2-}$, they are the least common materials in sediments: nitrates and ammonium (nitratine, nitre, etc.), or organically bound nitrogen associated with sediment, also forming nitrate deposits accumulated in arid and semi-arid regions, and elevated nitrogen concentrations in soil (Holloway and Dahlgren, 2002). They form in soil the following sedimentary materials: particles, pseudo particles, weathering alteration and diagenetic materials.

Sulphides rich soils: The sulphides are minerals with inorganic anions of sulfur chemical formula $\mathrm{S}^{2-}$. Soil rich in sulphides have pyrite and pyrrhotite. They are materials formed by biological sulfate reduction in marine anoxic environments (Trudinger, 1981). They form in soil the following sedimentary materials: particles, pseudo particles, weathering alteration and diagenetic materials.

Borates rich soils: The borates are minerals with borate anion, the orthoborate $\left({ }^{3-}\right)$ ion, $\left(\mathrm{BO}_{3}\right)^{3-}$. Soils rich in borates have borasite and borax. Borate deposits interlayered in continental volcaniclastic rocks (Helvaci and Alonso, 2000). They form in soil the following sedimentary materials: particles, pseudo particles, weathering alteration and diagenetic materials.
Native elements rich soils: The native elements occur in nature in uncombined form and with a distinct mineral structure. Native elements in soil are metallic and nonmetallic minerals (gold, diamond, silver, sulphur, uranium, among others). They form in soil the following sedimentary materials: particles, pseudo particles, and diagenetic materials.

Mixed compositional-mineralogical rich soils: Mixed soil include silicate-carbonate, silicate-phosphorite, oil shale, oil sands rich soil, etc.

\section{Feldsphatic quartz sandstone lithology example of Los Santos Formation}

One example of the use of general terminology that combines the proposed characterizations is presented below (see Table 4 and Figure 2, 3 and 4) (AvendañoSánchez and Cruz-Ceballos, 2017): genetic based on the parental substrate (Prs or Pds), the genetic materials (TDRM, ICM and IM), the amount of transformation that the three types of genetic components that make up the soil have (Tts, Hts, Mts or Sts), and the compositionalmineralogical one (Lithic rich soil, silicate rich soil, carbonate rich soil, etc.).

Soil profile developed on parental feldsphatic quartz arenite of Los Santos Formation (Prs), with Ipsf 1 to 7, slight transformed ( 8 to $29.65 \%$ ) evidenced by the presence of argillaceous matrix (kaolinite) and iron cement, moderately to heavy Icm (34 to $80 \%$ ) of very fine to medium qtz slight feldspathic sand, to slight granule size particles (Ipsf 1 to 5 and 7), heavy Icm (70.614\%) of argillaceous claystone (Illite) with very fine qtz sand (4.9\%), with slight to moderately $\operatorname{Im}(11.386$ to $30 \%)$ of coarse sand to granule-size agglutinate soil blades-shape pseudo-particles, sand-size plant fragments, roots, pores and water with TOC 3.02 to 0.386 .

Table 4. Specific genetic materials in horizons of soil profile developed on feldsphatic (fsp)-quartz (qtz) sandstones lithology sample and percentages of ICM, IC and TDRM. After Avendaño-Sánchez and Cruz-Ceballos (2017).

\begin{tabular}{|c|c|c|c|}
\hline $\begin{array}{c}\text { Inherited sequential } \\
\text { facies of the parental } \\
\text { substratum }\end{array}$ & $\begin{array}{c}\text { Soil } \\
\text { horizon }\end{array}$ & $\begin{array}{l}\text { Genetic general } \\
\text { material }\end{array}$ & Specific material \\
\hline \multirow{3}{*}{$\begin{array}{l}\mathbf{1}^{\text {st }} \text {. Very fine to } \\
\text { medium sandstone, } \\
\text { slightly granular slight } \\
\text { feldsphatic quartzose }\end{array}$} & \multirow{6}{*}{$\mathbf{A}$} & $\begin{array}{l}\text { Inherited- } \\
\text { conserved } 50 \%\end{array}$ & Very fine to medium sand-size slightly granule-size qtz particles \\
\hline & & Incorporated $25 \%$ & $\begin{array}{l}\text { Coarse sand to granule-size agglutinate soil blades-shape pseudo-particles } \\
(3 \%) \text {, sand-size plant fragments }(2 \%) \text {, roots, pores and water }(17 \%) \text {, TOC } \\
(3.02 \%)\end{array}$ \\
\hline & & TDR 25\% & Argillaceous matrix and iron oxides cement \\
\hline \multirow{3}{*}{$\begin{array}{c}2^{\text {nd }} \text { Very fine to } \\
\text { medium sandstone } \\
\text { slight feldsphatic } \\
\text { quartzose }\end{array}$} & & $\begin{array}{c}\text { Inherited- } \\
\text { conserved } 34 \%\end{array}$ & Very fine to medium qtz sand-size particles \\
\hline & & Incorporated $48 \%$ & $\begin{array}{l}\text { Granule to coarse pebbles-size ferruginous oxides ovoid shape nodules } \\
(30 \%) \text {, roots, pores and water }(16 \%) \text {, TOC }(2.02 \%)\end{array}$ \\
\hline & & TDR 18\% & Argillaceous matrix and iron oxides cement \\
\hline
\end{tabular}


Continuation Table 4.

\begin{tabular}{|c|c|c|c|}
\hline $\begin{array}{l}\text { Inherited sequential } \\
\text { facies of the parental } \\
\text { substratum }\end{array}$ & $\begin{array}{c}\text { Soil } \\
\text { horizon }\end{array}$ & $\begin{array}{l}\text { Genetic general } \\
\text { material }\end{array}$ & Specific material \\
\hline \multirow{3}{*}{$\begin{array}{c}3^{\text {rd }} \text { Fine to medium } \\
\text { sandstone slight silty } \\
\text { slight feldsphatic } \\
\text { quartzose }\end{array}$} & \multirow{9}{*}{ B } & $\begin{array}{c}\text { Inherited- } \\
\text { conserved 51\% }\end{array}$ & Fine to medium sand lightly silty qtz particles \\
\hline & & Incorporated $30 \%$ & $\begin{array}{l}\text { Ferruginous or manganese oxides on mottle structure }(5 \%) \text {, granule to } \\
\text { coarse pebbles-size ferruginous oxides ovoid shape nodules }(7 \%) \text {, roots, } \\
\text { pores and water }(17 \%) \text {, TOC }(1.09 \%)\end{array}$ \\
\hline & & TDR 19\% & Argillaceous matrix and iron oxides cement \\
\hline \multirow{3}{*}{$\begin{array}{l}4^{\text {th }} \text { Fine to medium } \\
\text { sandstone slight } \\
\text { feldsphatic quartzose }\end{array}$} & & $\begin{array}{c}\text { Inherited- } \\
\text { conserved 53\% }\end{array}$ & Fine to medium qtz sand \\
\hline & & Incorporated $17 \%$ & $\begin{array}{l}\text { Ferruginous or manganese oxides on mottle structure }(5 \%) \text {, roots, pores and } \\
\text { water }(12 \%) \text {, TOC }(0.347 \%)\end{array}$ \\
\hline & & TDR 29,65\% & Argillaceous matrix and iron oxides cement \\
\hline \multirow{3}{*}{$\begin{array}{l}5^{\text {th }} \text { Fine to medium } \\
\text { sandstone slight } \\
\text { feldsphatic quartzose }\end{array}$} & & $\begin{array}{c}\text { Inherited- } \\
\text { conserved 55\% }\end{array}$ & $\begin{array}{l}\text { Fine to medium sand fsp particles }(5 \%) \text {, fine to medium sand qtz particles } \\
(50 \%)\end{array}$ \\
\hline & & Incorporated $17 \%$ & $\begin{array}{l}\text { Ferruginous or manganese oxides on mottle structure }(7 \%) \text {, pores and water } \\
(10 \%) \text {, TOC }(0.209 \%)\end{array}$ \\
\hline & & TDR $28 \%$ & Argillaceous materials and iron oxides cement \\
\hline \multirow{3}{*}{$\begin{array}{c}\mathbf{6}^{\text {th }} \text { Argillaceous } \\
\text { claystone slight sand } \\
\text { quartzose }\end{array}$} & \multirow{6}{*}{ C } & Inherited $70,614 \%$ & $\begin{array}{l}\text { Argillaceous claystone (Illite) }(65.714 \%) \text {, very fine qtz sand particles } \\
(4.9 \%)\end{array}$ \\
\hline & & $\begin{array}{l}\text { Incorporated } \\
11,386 \%\end{array}$ & Water (11.21), TOC $(0.386 \%)$ \\
\hline & & TDR $18 \%$ & Argillaceous claystone (Kaolinite) \\
\hline \multirow{3}{*}{$\begin{array}{l}7^{\text {th }} \text { Fine to medium } \\
\text { sandstone slight } \\
\text { feldsphatic quartzose }\end{array}$} & & $\begin{array}{c}\text { Inherited- } \\
\text { conserved } 80 \%\end{array}$ & $\begin{array}{l}\text { Fine to medium sand fsp particles }(8 \%) \text {, fine to medium sand qtz particles } \\
(72 \%)\end{array}$ \\
\hline & & Incorporated $12 \%$ & Ferruginous or manganese oxides on mottle structure $(7 \%)$, pores $(5 \%)$ \\
\hline & & TDR 8\% & Argillaceous matrix and iron oxides cement \\
\hline
\end{tabular}

Feldspar particle (fsp), quartz particle (qtz), total organic content (TOC).

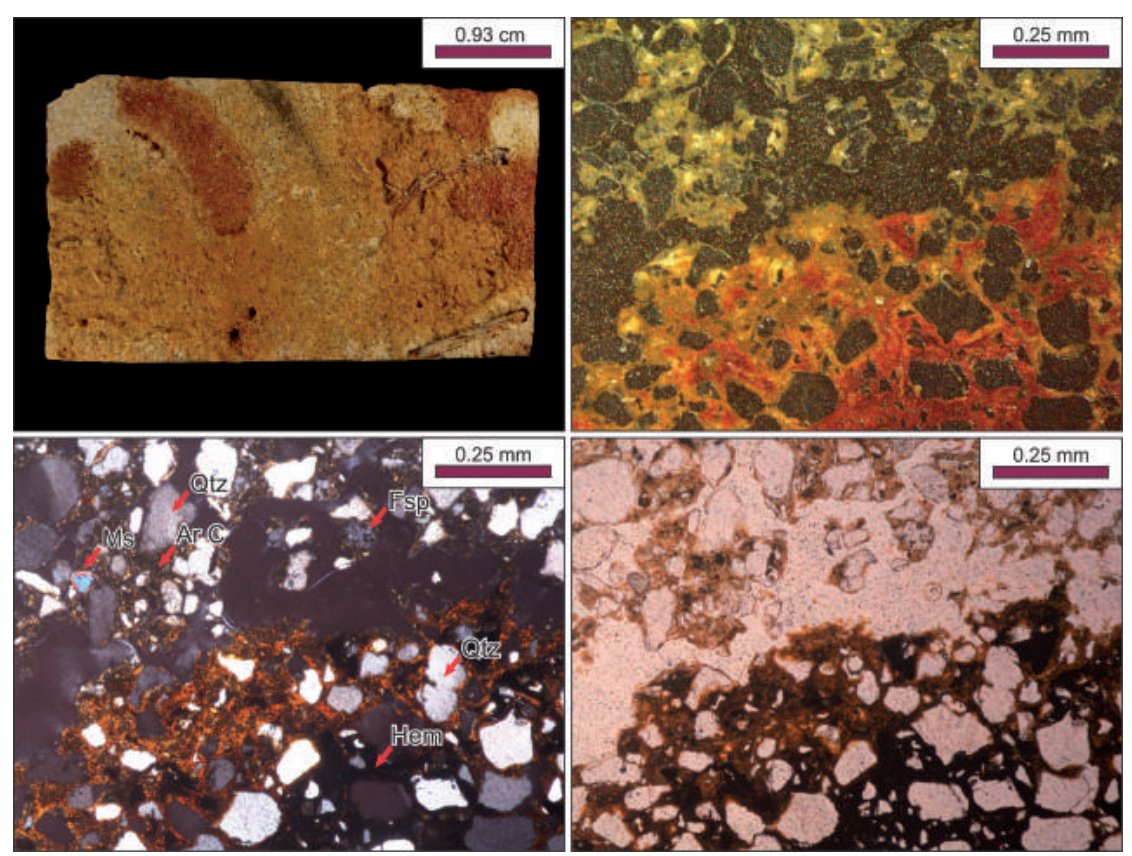

Figure 4. Sample, horizon B of soil developed on inherited parental sequential facies of 3th medium to very fine feldspathic quartz sandstones from Los Santos Formation (Santander - Colombia, northwestern part of South America) (Avendaño-Sánchez and Cruz-Ceballos, 2017) of Berriasian age (Etayo-Serna and Rodríguez, 1985). A. Polished surface of sample with natural light, showing parental rocks with nodule formed by incorporated iron oxides (ovoid red areas), and incorporated roots of plants in the lower right. B. Thin section of the sample with reflected light and without polarization. $\mathbf{C}$. Thin section of the sample with crossed nicols. D. Thin section of the sample with parallel nicols, all of them showing the following: inherited and conserved fine to very fine sand of clastic quartz (Qtz) and clay oxidized illite, and clay oxidized kaolinite (ArC) transformed by weathering of clastic feldspar (Fsp) sand, and iron oxides (hematite (Hem)) incorporated. Clastic muscovite (Ms). 


\section{CONCLUSIONS}

The weathering process overprint the new soil facies sequence structure of the soil (Ssf) (horizon A, B and $\mathrm{C}$ ) over the parental facies sequence (Pssf) (e.g., bed intercalation, etc.), both facies sequence Ssf and Pssf need their recognition in the genetic geological classifications of the soil.

The Isf and the overprints Ssf contributes significantly to the behavior of soils, both for agricultural purposes, also in engineering-geotechnical soil uses, or for natural slope stability and threat, vulnerability and risk.

The genetic classification of soil has two different approaches, the first is the relationship of the soil with the parent substrate, and the second one, is based on the specific genetic materials and structures that form the soil. According to parental substratum there are Prs and Pds.

The soil has three kinds of specific genetic materials and structures, first are the inherited-conserved materials (ICM), those that come from the parental material without having undergone modifications, second are the transformed materials (TDRM), they would be those parts of the parent substratum that were altered, and three, the incorporated materials (IM), they would be all those biogenic or abiogenic materials introduced to the soil system, which were not part of the original parent material, nor of its possible transformations.

The soils can be classified according to the intensity of the transformation, which can be quantified from the percentages of the three constituents, TDRM, ICM and IM, as totally, heavy, moderately and slightly transformed, or heavily inherited or conserved soils.

As a complement to the genetic classification and because the mineral composition contributes significantly to the behavior of soils, it is necessary to propose the use of compositional-mineralogical classification of the soil as well: soil rich in lithics, or silicates, or carbonates, or mixed like silicate and organic, or organic shale rich soil.

Finally, it is convenient to use in the genetic classification of soils, and integrate it into a complete classification, genetic-textural with compositional-mineralogical.

\section{ACKNOWLEDGMENTS}

This study was supported by Universidad Industrial de Santander. Thanks to the School of Geology, and also to the research group of Energy and Other Non-Renewable Resources Research Group of the Universidad Industrial de Santander. Thanks to Esperanza Revelo Jiménez for the style correction of the document, thanks also to the evaluators of the document Modesto Portilla and María Teresa Flórez for the critical reading of the document and the great contributions that allowed to improve the document.

\section{REFERENCES}

Al-Amoundi, O.S.B., and Abduljauwad, S.N. (1995). Compressibility and collapse characteristics of arid saline sabkha soils. Engineering Geology, 39(3-4), 185-202. doi: 10.1016/00137952(95)00016-9.

Assereto, R.L., and Kendall, C.G. (1971). Megapolygons in Ladinian limestones of Triassic of Southern Alps: evidence of deformation by penecontemporaneous desiccation and cementation. Journal of Sedimentary Petrology, 41(3), 715-723.

ASTM D2487-06. Standard Practice for Classification of Soils for Engineering Purposes (Unified Soil Classification System). West Conshohocken, PA, ASTM International. doi: 10.1520/D2487-06.

ASTM D3282-93(2004)e1. Standard Practice for Classification of Soils and Soil Aggregate Mixtures for Highway Construction Purposes. West Conshohocken, PA, ASTM International. doi: 10.1520/D3282-93R04E01.

Avendaño-Sánchez, G.M., and Cruz-Ceballos, L.F. (2017). Geological classification of modern soils of regolith, proposal for new structure of classification and nomenclature. Thesis, Universidad Industrial de Santander, Colombia.

Baize, D., and Girard, M.C. (2008). Référentiel pédologique. Versailles: Association française pour l'étude du sol (Afes). 
Beck, M.A., and Sanchez, P.A. (1994). Soil phosphorus fraction dynamics during 18 years of cultivation on a Typic Paleudult. Soil Science Society of America Journal, 58(5), 1424-1431. doi: 10.2136/ sssaj1994.03615995005800050021x.

Bellamy, J. (1977). Subsurface expansion megapolygons in Upper Jurassic dolostone (Kimmerdge, UK). Journal of Sedimentary Petrology, 47(3), 973-978.

Benedict, J.B. (1979). Fossil ice-wedge polygons in the Colorado Front Range: origin and significance. GSA Bulletin, 90(2), 173-180. doi: 10.1130/0016-7606(1979)90<173:FIPITC $>2.0$. $\mathrm{CO} ; 2$.

Birkeland, P.W. (1999). Soils and geomorphology. New York: Oxford University Press.

Boggs, S. (2006). Principles of sedimentology and stratigraphy. 4th edition. Upper Saddle River: Prentice Hall.

Bohra, A., Kotlia, B.S., Laskar, A.H., and Yadava, M.G. (2014). Evidence of Late Quaternary seismicity from Yunam Tso, Lahaul and Spiti, NW Himalaya, India. Journal of Earth System Science, 123(3), 603-616. doi: 10.1007/s12040014-0415-2.

Bornemann, L., Herbst, M., Welp, G., Vereecken, H., and Amelung, W. (2011). Rock fragments control size and saturation of organic carbon pools in agricultural topsoil. Soil Science Society of America Journal, 75(5), 1898-1907. doi: 10.2136/ sssaj2010.0454.

Bortoluzzi, E.C., Pérez, C., Ardisson, J., Tiecher, T., and Caner, L. (2015). Occurrence of iron and aluminum sesquioxides and their implications for the P sorption in subtropical soils. Applied Clay Science, 104, 196-204. doi: 10.1016/j. clay.2014.11.032.

Brantley, S.L., Goldhaber, M.B., and Ragnarsdottir, K.V. (2007). Crossing disciplines and scales to understand the critical zone. Elements, 3(5), 307314. doi: 10.2113/gselements.3.5.307.
Bridges, E.R. (1990). Soil horizon designation. Technical paper 19. Wageningen: International Soil Reference and Information Center (ISRIC).

Buol, S.W., Hole, F.D., McCracken, R.J., and Southard, R.J. (1997). Soil genesis and classification. Ames: Iowa State University Press.

Carvalho-Filho, A., India, A., Fink, J., and Curi, N. (2015). Iron oxides in soils of different lithological origins in Ferriferous Quadrilateral (Minas Gerais, Brazil). Applied Clay Science, 118, 1-7. doi: 10.1016/j.clay.2015.08.037.

Casagrande, A. (1948). Classification and identification of soils. Transactions of the American Society of Civil Engineering, 113, 901-991.

Chesworth, W. (2007). Encyclopedia of soil science. Dordrecht: Springer.

Conte, E., Anghinoni, I., and Rheinheimer, D.S. (2002). Fósforo da biomassa microbiana e atividade de fosfatase ácida após aplicação de fosfato em solo no sistema plantio direto. Revista Brasileira de Ciência do Solo, 26(4), 925-930. doi: 10.1590/ S0100-06832002000400009.

Cruz-Guevara, L.E., Cruz-Ceballos, L.F., AvendañoSánchez, G.M., and Villamizar-Cáceres, J.L. (2017). Geological soil or regolith classification, a proposal for a new classifying and naming structure of sedimentary deposits and rocks. $X V I$ Congreso Colombiano de Geología, Santa Marta, Colombia.

Dana, E.S., and Ford, W.E. (1922). A text book of mineralogy, with an extended treatise on crystallography and physical mineralogy. New York: John Wiley and Sons.

Dana, E.S., and Hurlbut, C.S. (1959). Manual de mineralogía, tratado moderno para la enseñanza en universidades y escuelas especiales y para la guía de ingenieros de minas y geólogos. $2 \mathrm{da}$ edición. Barcelona: Editorial Reverté, S.A.

Do Campo, M., Nieto, F., Albanesi, G.L., Ortega, G., and Monaldi, C.R. (2017). Outlining the thermal posdepositional evolution of the Ordovician 
successions of northwestern Argentina by clay mineral analysis, chlorite geothermometry and Kübler index. Andean Geology, 44(2), 179-212. doi: $10.5027 /$ andgeoV44n2-a04.

Dodd, R.J., and Sharpley, A.N. (2015). Recognizing the role of soil organic phosphorus in soil fertility and water quality. Resources, Conservation and Recycling, 105(Part B), 282-293. doi: 10.1016/j. resconrec.2015.10.001.

Dvorak, J., and Novak, L. (1994). Soil Conservation and Silviculture. Prague: Elsevier Science.

Dylik, J., and Maarleveld, G.C. (1967). Frost cracks, frost fissures and related. Polygons. Mededelingen van de Geologische Stichting Nieuwe Serie, 18, 7-21.

Eswaran, H., Rice, T., Ahrens, R., and Stewart, B. (2003). Soil Classification. A Global Desk Reference. Washington, DC: CRC Press.

Etayo-Serna, F., y Rodríguez, G. (1985). Edad de la Formación Los Santos. Publicaciones Geológicas Especiales del Ingeominas, 16, 351-336.

FAO. (2015a). Healthy soils are the basis for healthy food production. Food and Agriculture Organization of the United Nations.

FAO. (2015b). World reference base for soil resources 2014. International soil classification system for naming soils and creating legends for soil maps. Updated 2015. Roma: World soil resources reports, 106.

Fink, J.R., India, A., Bavaresco, J., SánchezRodríguez, A., Barrón, V., Torrent, J., and Bayer, C. (2016). Diffusion and uptake of phosphorus, and root development of corn seedlings, in three contrasting subtropical soils under conventional tillage or no-tillage. Biology and Fertility of Soils, 52(2), 203-210. doi: 10.1007/s00374-015-1067-3.

Friedman, G.M. (1997). Dissolution-collapse breccias and paleokarst resulting from dissolution of evaporite rocks, especially sulfates. Carbonates and Evaporites, 12(1), 53-63.
Geological Survey of Western Australia. (2013). Revised classification system for regolith in Western Australia, and the recommended approach to regolith mapping. West Perth: Geological Survey of Western Australia.

Helvaci, C., and Alonso, R.N. (2000). Borate deposits of Turkey and Argentina; a summary and geological comparison. Turkish Journal of Earth Sciences, 9(1), 1-27.

Holloway, J.M., and Dahlgren, R.A. (2002). Nitrogen in rock: occurrences and biogeochemical implications. Global Biogeochemical Cycles, 16(4), 1-17. doi: 10.1029/2002GB001862.

Huang, P.T., Patel, M., Santagata, M.C., and Bobet, A. (2009). Classification of organic soils, Final Report. West Lafayette: Joint Transportation Research Program.

IDEAM (2017). Clasificación Climática Caldas-Lang 2012. Consulted on 14 august of 2017. https:// www.datos.gov.co/Ambiente-y-DesarrolloSostenible/Clasificaci-n-Clim-tica-Caldas-Lang2012/3akx-3ph5.

IUSS Working Group WRB (2015). World Reference Base for soil resources 2014, International soil classification system for naming soils and creating legends for soil maps. Rome: World Soil Resources Report.

Jahn, R., Blume, H.P., Asio, V.B., Spaargaren, O., and Schad, P. (2006). Guidelines for soil description. Roma: Food and agriculture organization of the United Nations.

Kämpf, N., and Schwertmann, U. (1982). The $5-\mathrm{M}-\mathrm{NaOH}$ concentration treatment for iron oxides in soils. Clays and Clay Minerals, 30(6), 401-408.

Kew, G., and Gilkes, R. (2006). Classification, strength and water retention characteristics of lateritic regolith. Geoderma, 136(1-2), 184-198. doi: 10.1016/j.geoderma.2006.03.025. 
Kidwell, S.M., Fürsich, F., and Aigner, T. (1986). Conceptual framework for the analysis and classification of fossil concentrations. Palaios, 1(3), 228-238.

Ko, T.H. (2008). Removal of hydrogen sulfur from coal-derived gas by iron oxides in various oxisols. Environmental Engineering Science, 25(7), 969973. doi: 10.1089/ees.2007.0133.

Lavaut, W. (2018). A geological classification for the rocks of weathering. Petroleum Science and Engineering, 2(1), 1-6. doi: 10.11648/j. pse.20180201.11.

Macar, P. (1948). Les pseudo-nodules du Famennien et leur origine. Annales de la Société Géologique de Belgique, 72, 47-74.

Martinazzo, R., Rheinheimer, D.S., Gatiboni, L.C., Brunetto, G., and Kaminski, J. (2007). Fósforo microbiano do solo sob sistema plantio direto em resposta à adição de fosfato solúvel. Revista Brasileira de Ciência do Solo, 31(3), 563-570. doi: 10.1590/S0100-06832007000300016.

Merrill, G.P. (1897). A treatise on rocks, rockweathering, and soil. Washington: Macmillan \& Co.

Middleton, G.V. (2003). Encyclopedia of sediments, and sedimentary rocks. Dordrecht: Springer.

Millot, G. (1964). Géologie des Argiles, altérations, sédimentologie, géochimie. Paris: Masson et Cie.

Pariente, S., and Lavee, H. (2003). Soil organic matter and degradation. Soil conservation and protection for Europe, 83-88.

Patton, F.D. (1966). Multiple modes of shear failure in rock and related materials. Ph.D. Thesis, University of Illinois, USA.

Patton, F.D., and Deere, D.U. (1971). Significant geologic factor in rock slope stability. Symposium on the Theoretical Background to the Planning of Open Pit Mines with Special Reference to Slope Stability. South Africa.

Peryt, T.M. (1983). Coated Grains. Berlin: SpringerVerlag.
Retallack, G.J. (1977). Triassic palaeosols in the upper Narrabeen group of New South Wales. Part II: Classification and reconstruction. Journal of the Geological Society of Australia, 24(1-2), 19-35. doi: 10.1080/00167617708728964.

Robertson, P.K., and Cabal, K.L. (2015). Guide to Cone Penetration Testing for Geotechnical Engineering. Signal Hill: Gregg Drilling and Testing, Inc.

Schaefer, C.E.G.R., Fabris, J.D., and Ker, J.C. (2008). Minerals in the clay fraction of Brazilian Latosols (Oxisols): a review. Clay Minerals, 43(1), 137154.

Scott, K., and Pain, C. (2008). Regolith science. Collingwood: CSIRO Publishing.

Smith, B. (1916). Ball and pillow-form structures in sandstones. Geological Magazine, 3(4), 146-156. doi: 10.1017/S0016756800199637.

Soil Classification Working Group. (1998). The Canadian System of Soil Classification. 3rd ed. Ottawa: NRC Research Press.

Soil Survey Staff. (1999). Soil Taxonomy. A basic system of soil classification for making and interpreting soil surveys. 2 nd edition. Agricultural Handbook 436. Washington DC: Natural Resources Conservation Service, USDA.

Soil Survey Staff. (2014). Keys to soil taxonomy. 12th edition. Washington: U.S. Department of Agriculture, Natural Resources Conservation Service.

Taylor, G. (2006). Fundamentals of regolith geology. Regolith 2006 proceeding of the CRC LEME Regolith Symposium. Consolidation and dispersion of ideas. Hahndorf, South Australia.

Trescases, J.J. (1975). L'Évolution géochemique supergène des roches ultrabasiques en zone tropicale: Formation de gisements nickelifères de de Nouvelle-Calédonie. Strasbourg: Mémoires ORSTOM.

Tiessen, H., Stewart, J.W.B., and Cole, C.V. (1984). Pathways of phosphorus transformations in soils of differing pedogenesis. Soil Science Society of 
American Journal, 48(4), 853-858. doi: 10.2136/ sssaj1984.03615995004800040031x.

Trudinger, P.A. (1981). Origins of sulphide in sediments. BMR Journal of Australian Geology and Geophysics, 6(4), 279-285.

Udden, J.A. (1918). Fossil ice crystals: An instance of practical value of "pure science". Bulletin of the University of Texas, 1821, 3-8.

Wager, L.R., Brown, G.M., and Wadsworth, W.J. (1960). Types of igneous cumulates. Journal of Petrology, 1(1), 73-85. doi: 10.1093/ petrology/1.1.73.

Wang, X., Liu, F., Tan, W., Li, W., Feng, X., and Sparks, D. (2013). Characteristics of phosphate adsorption-desorption onto ferrihydrite: comparison with well-crystalline $\mathrm{Fe}$ (hydr) oxides. Soil Science, 178(1), 1-11. doi: 10.1097/ SS.0b013e31828683f8.
Wilson, M.J. (1975). Chemical weathering of some primary rock-forming minerals. Soil Science, $119(5), 349-355$.

Wilson, M.J. (2013). Sheet silicates, clay minerals. In: W.A. Deer, R.A. Howie, J. Zussman (Eds.). Rock-forming minerals. London: The Geological Society.

Luis Enrique Cruz-Guevara
ORCID: 0000-0002-8345-4870
Luis Felipe Cruz-Ceballos
ORCID: 0000-0002-4339-2302
Gladys Marcela Avendaño-Sánchez
ORCID: 0000-0001-8215-5863
Mario García-González
ORCID: 0000-0003-4328-0885

Received: 17 May 2019

Accepted: 19 November 2019 